\title{
The Moderating Effect of COVID-19 on the Relationship Between Corporate Risk Disclosure and Investor Perceived Confidence
}

\author{
Amy Yeo Chu May ${ }^{1, *}$ Ooi Xin $\mathrm{Ru}^{2}$ Felizia Arni Rudiawarni ${ }^{3}$ \\ ${ }^{1}$ Faculty of Accountancy, Finance and Business Tunku Abdul Rahman University College, Malaysia \\ ${ }^{2}$ Boardroom Corporate Services (KL) Sdn Bhd, Petaling Jaya, Malaysia \\ ${ }^{3}$ Faculty of Business and Economics, University of Surabaya, Indonesia \\ *Corresponding author. Email: yeocm@tarc.edu.my
}

\begin{abstract}
The COVID-19 pandemic has affected a multifaceted human existence and investors who have to deal with the uncertainty of the stock market is not exempted. Therefore, the study aims to investigate to what extent corporate risk disclosure affects the investors' perceived confidence and trust. Our study employed partial least square analysis on the research framework and hypotheses through Smart-PLS software using data collected from 108 Malaysian individual investors. This study examined three theories, namely Stakeholder, Signalling and Prospect theories, representing the respective variables of investor perceived confidence and trust, corporate risk disclosures, and COVID-19. Based on the theories, the assumption is that investors (as part of stakeholders) will have an increased perception of more losses in times of crisis if they are not given any assurance and transparent disclosure signals. The extant study revealed a direct positive relationship between financial, operations and strategic risk disclosure to perceived investor confidence and trust. The results also indicated that most investors concurred that COVID-19 significantly impacts investor perceived confidence and trust in relation to the three stated risks.
\end{abstract}

Keywords: Perceived Investor Confidence; Perceived Investor Trust; COVID-19; Financial Risk Disclosure; Operations Risk Disclosure; Strategic Risk Disclosure

\section{INTRODUCTION}

The presence of the novel coronavirus (COVID19) has sparked a global health crisis resulting in a pandemic that has affected the daily lives of people all around the world, socially and economically. A report from the International Organization of Securities Commissions (ISCO) during the year 2020 has found and observed that the COVID-19 pandemic itself has created a stressful environment which could possibly bring harm or losses to individual or retail investors through conduct risk. Additionally, they have also stated the importance of disclosure about COVID-19's impact on the company's financial position, operating performance and future prospect to investors and other stakeholders, who require highquality transparent information. Due to the special circumstances of the pandemic's effects, many recent studies worldwide have conducted in the midst of the pandemic. Some of which included COVID-19's effects on the stock market behavior [1][2][3] and the economic effects of general financial well-being [4]. In addition, many of these recent studies are based outside of Malaysia, where the regulations on handling the pandemic may be completely different.

While there are many studies focusing on the effects of COVID-19 on investors' reactions by observing and analysing the stock market trading during such uncertain times [2] [3] [5], there is a lack of studies on understanding how investors feel and perceive the situation at the moment. Recent studies on COVID-19's impact on investor behaviour being related to both prospect and signalling theories as confirmed by Budiarso et. al. [2]. 


\section{LITERATURE REVIEW AND HYPOTHESES DEVELOPMENT}

Financial risk disclosures are an important component in decreasing information asymmetry, implying that their presence reduces investors' uncertainties [6]. Similarly, Hassan \& Saleh [7] have found that the financial disclosure is valuable in investment decision-making. It implicates its usefulness and importance towards investors. This is further supported by Lawrence's [8] study where it is found that individuals have the tendency to invest in companies who possess clear and concise financial disclosures. Overall, risk disclosures have been proven to provide useful information to investors [9]. When financial risk disclosures are provided, it is improving investors' trust and confidence and other stakeholders as well [10]. Thus, the following hypothesis is formed:

H1: There is a positive association between financial risk disclosure and perceived investor confidence and trust.

Operational risk disclosures also have its own impact compared to financial risk disclosures. The impacts of operational loss events can significantly affect the market values of banks and other financial institutions, implying that operational risk information is an important factor in making investment decisions [11] [12]. It is proven by studies that emphasize operational risk disclosures for effective market discipline [13][14]. Thus, such risk disclosures play a great importance in informational relevance and are implied to affect investors [15]. Benlemlih et. al. [16] emphasizes that disclosures help companies build positive reputations and trust with their investors as they have better information, mitigating the company's' operational risks. Thus, it has solidified that increasing disclosures of information improve the average investor's confidence [17] and the trust [18]. Thus, the following hypothesis is formed:

H2: There is a positive association between operational risk disclosure and perceived investor confidence and trust.

According to Chauhan and Kumar [19], various non-financial disclosures have been found to have positive valuation effects on a firm's overall value, implying positive perceptions. In addition, Kim \& Yasuda [20] have found that there is a positive relationship between the number of items in business risk disclosure reports and total risk, which implies that the disclosures (which include strategic risks taken by the firm) have an increasing impact on investors' assessment of firm risk. Strategic risk is a non-financial risk related to the fundamental economy. An economic environment with high uncertainty will affect the company's risk and performance, which will affect the company's ability to create wealth for stockholders [21]. Regarding the relation between disclosure with confidence and trust, Lee \& Shailer [17] have unfolded that increased disclosure of corporate governance information improves the average investor's confidence. In the same vein, Tong [18] argued that perceived importance of corporate trust is related in forms of corporate attributes in risk disclosure. Cabedo and Tirado [21] stated that the sensitivity of the company's risk to economic changes is different; therefore, the more transparent disclosure of strategic risk will make it easier for investors to estimate the risks in certain investments, which further increases investors' confidence in the company. Thus, the following hypothesis is formed:

H3: There is a positive association between strategic risk disclosure and perceived investor confidence and trust.

The COVID-19 pandemic has caused significant impact on the financial risk attitudes in general with many being more prudent in taking any form of financial risks [22]. Furthermore, Yildrim \& Guler [23] in their research revealed there was an increased perceived risk related to the severity of COVID-19. Prior studies also have found that financial risk disclosures are relevant and investors positively gravitate towards it with confidence and trust [7][8][10]. Conversely, Moumen et. al. [24] discovered that investors tend to rely on another source of information due to proprietary costs' tendency to affect the perceived relevance of risk disclosure from annual reports. Moreover, COVID19 has led to a sharp increase in equity market exposure, which implies low market stability and investor confidence [25]. Thus, the following hypothesis is formed:

H4: The impact of COVID-19 would influence the relationship between financial risk disclosure and perceived investor confidence and trust.

According to Zimmer et al. (2010) [26], information relevance directly impacts risk beliefs and attitudes. When people perceive that the information requested is relevant, their risk perceptions diminish and develop positive attitudes toward information shared with them. It is supported by Derouiche et. al. [27] who found that firms have 
better efficiency when a firm discloses their operational risk exposures. Nevertheless, it was found that when the operational risk occurs and is disclosed, there would be a negative market reaction, implying the presence of uncertainty and low investor confidence [28]. COVID-19 could possibly amplify these effects negatively and increase the uncertainty and fear investors may have leading to low confidence and trust [29]. Thus, the following hypothesis is formed:

H5: The impact of COVID-19 would influence the relationship between operations risk disclosure and perceived investor confidence and trust.

The disclosure of a firm's strategic risks can clarify any future or external events that may or may not affect the company's decision and its activities, this includes various non-financial information that investors may care about. According to Chauhan \& Kumar [19], firms that disclose non-financial information suffer less during a financial crisis. This supports Lopatta et. al. [30] who found that investors highly value companies that include critical global developments within their reports such as COVID19. Nevertheless, Elshandidy \& Zeng [31] found that any additional risk disclosure does not matter or add value for investors and is considered merely a routine. In addition, strategic risks including external shock factors such as government economic policy uncertainty may result in decreased stock price reactions, implying decrease in investor confidence [32]. Furthermore, Liu et. al. [29] found that COVID19 has a significant negative impact on stock markets worldwide, implying investors' fear of investment risks brought on by COVID-19. Thus, the following hypothesis is formed:

H6: The impact of COVID-19 would influence the relationship between strategic risk disclosure and perceived investor confidence and trust.

Figure 1: Proposed Conceptual Framework

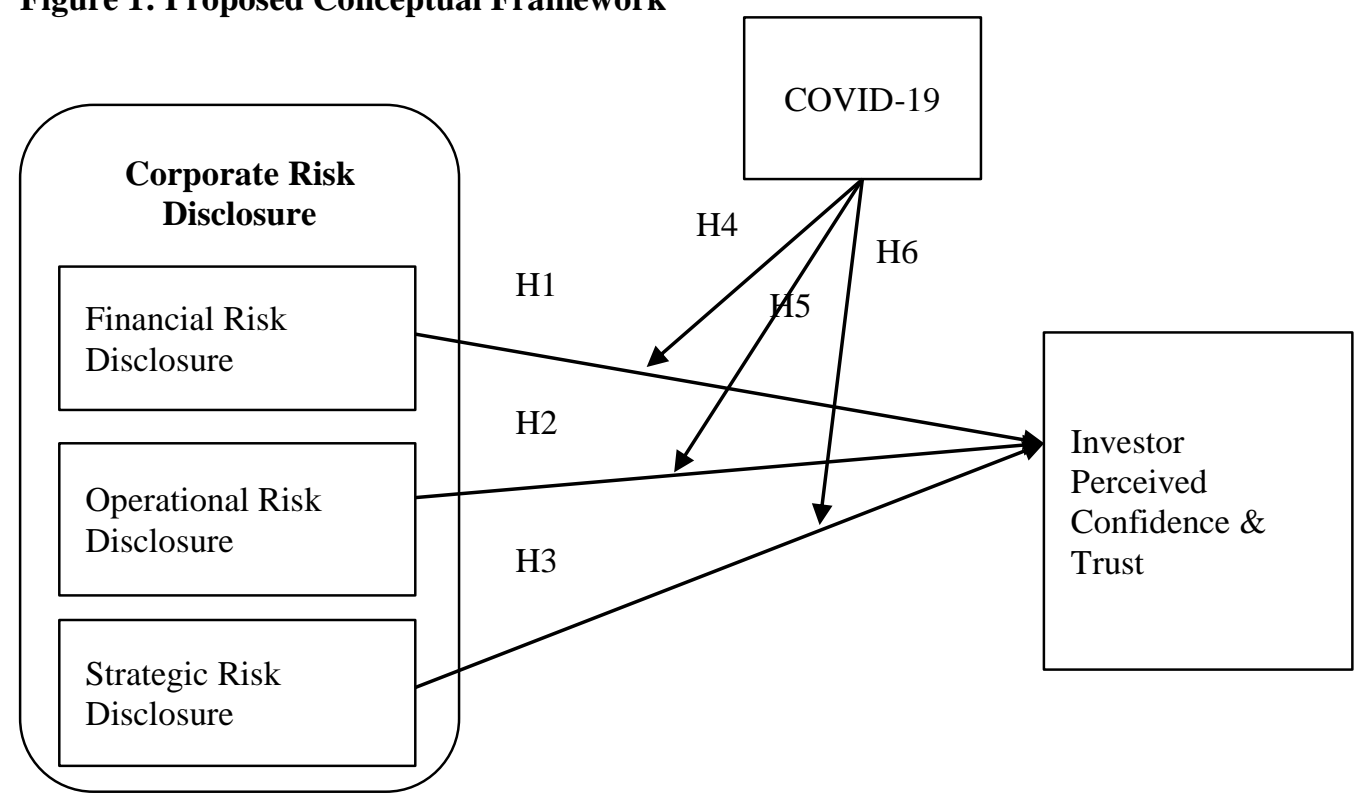

\section{RESEARCH METHODS}

Our study employed cross-sectional methods where respondents' quantitative information will be collected only once [33] [34]. Since this study's purpose is to measure the degree of relation between two or more different variables, the use of descriptive research under correlational design is most suited [35]. We used online questionnaires to the respondents. Generally, online surveys have poor response rates due to issues such as survey fatigue and emails being filtered to the spam folder which are common phenomena [36]. This issue is the same during COVID-19, where studies like Hensen et. al. [37] have acknowledged several challenges of remote quantitative data collection methods, including higher non-responses than face-to-face methods.

Furthermore, Prommegger et. al. [38] has addressed the difficulties of data collection in between different waves of COVID-19 and has found that it influences their respondent's perception and intentions. Thus, many of these issues add to the 
respondents' reluctance to disclose their own perceptions. Hence, this study has created selfadministered online questionnaires via Google Forms as it is a free user-friendly surveying tool with a simple interface. The design of the questionnaire was adapted from several studies such as Linsley \& Shrives [39], Amran et. al., [40], Abdullah et. al. [41], Wilson [42], Lucarelli et. al. [43] and Tong [18]. The questionnaire was pre-tested to a sample of 30 respondents in order to ensure its clarity.

\subsection{Sampling Design}

This study's population sample shall be individual retail investors residing in Malaysia who are interested in looking at corporate risk disclosures and annual reports of the companies they have invested in. Kalay [44] has found that investors that demand disclosures are particularly driven by their abilities to use such information. Thus, the reason for selecting them is because they understand the importance of disclosures and take them into account when making investment decisions for themselves [45][46]. Therefore, they can express their perceptions on whether they feel confident and have an element of trust towards such disclosures in the midst of COVID-19. In addition, by taking into consideration that this study intends to apply structural equation modeling (SEM), issues in regard to sample sizes are that there is no general consensus on such matters, and a minimum sample size of 200 for any SEM is recommended [47]. According to Ramayah et. al. [48], the recommended minimum number of observations for PLS-SEM is merely 30 to 100 observations. On the other hand, another rough guideline for estimating minimum sample size is the 10 times rule where the sample size should be 10 times the maximum number of arrowheads pointing at a latent variable anywhere in the PLS path model [49]. To analyse the data collected from this study, the SPSS and SmartPLS software were employed to measure commonly used statistical procedures and generate statistical analysis. Notably, SmartPLS software employs a variance-based structural equation modelling (SEM) using the partial least squares (PLS) path modelling method.

\subsection{Data Analysis and Discussion}

\section{Common Method Variance}

As indicated in Table 1, if the total variance for a single factor is less than $50 \%$, this proves that the data sample is not affected by common method bias according to Harman's single factor test [50]. This study's total variance for a single factor is $49.8 \%$ (as shown in Table 1) which is close to but has not exceeded the $50 \%$ cut-off, which indicates that the data results would not be very affected by common method bias.

Table 1: Common Method Variance Assessment

\begin{tabular}{|c|c|c|c|c|c|c|}
\hline \multicolumn{7}{|c|}{ Total Variance Explained } \\
\hline Factor & Total & $\begin{array}{l}\% \text { of } \\
\text { Variance }\end{array}$ & Cumulative $\%$ & Total & $\begin{array}{l}\% \text { of } \\
\text { Variance }\end{array}$ & $\begin{array}{l}\text { Cumulative } \\
\%\end{array}$ \\
\hline 1 & 18.419 & 51.165 & 51.165 & 17.944 & 49.845 & 49.845 \\
\hline 2 & 3.100 & 8.611 & 59.776 & & & \\
\hline 3 & 2.227 & 6.186 & 65.962 & & & \\
\hline 4 & 0.930 & 2.583 & 68.545 & & & \\
\hline 5 & 0.913 & 2.537 & 71.082 & & & \\
\hline 6 & 0.789 & 2.191 & 73.273 & & & \\
\hline 7 & 0.734 & 2.040 & 75.313 & & & \\
\hline 8 & 0.695 & 1.930 & 77.243 & & & \\
\hline 9 & 0.665 & 1.848 & 79.091 & & & \\
\hline 10 & 0.616 & 1.711 & 80.802 & & & \\
\hline 11 & 0.552 & 1.533 & 82.335 & & & \\
\hline 12 & 0.548 & 1.522 & 83.858 & & & \\
\hline 13 & 0.484 & 1.344 & 85.202 & & & \\
\hline 14 & 0.440 & 1.222 & 86.423 & & & \\
\hline 15 & 0.404 & 1.123 & 87.546 & & & \\
\hline 16 & 0.391 & 1.087 & 88.633 & & & \\
\hline 17 & 0.369 & 1.025 & 89.658 & & & \\
\hline 18 & 0.347 & 0.963 & 90.621 & & & \\
\hline 19 & 0.333 & 0.926 & 91.547 & & & \\
\hline
\end{tabular}




\begin{tabular}{llll}
20 & 0.317 & 0.880 & 92.427 \\
21 & 0.280 & 0.778 & 93.204 \\
22 & 0.260 & 0.722 & 93.926 \\
23 & 0.249 & 0.691 & 94.618 \\
24 & 0.218 & 0.604 & 95.222 \\
25 & 0.205 & 0.568 & 95.790 \\
26 & 0.193 & 0.535 & 96.325 \\
27 & 0.188 & 0.523 & 96.848 \\
28 & 0.169 & 0.469 & 97.317 \\
29 & 0.159 & 0.441 & 97.757 \\
30 & 0.151 & 0.420 & 98.177 \\
31 & 0.147 & 0.409 & 98.586 \\
32 & 0.131 & 0.363 & 98.949 \\
33 & 0.115 & 0.319 & 99.268 \\
34 & 0.099 & 0.276 & 99.544 \\
35 & 0.089 & 0.247 & 99.791 \\
36 & 0.075 & 0.209 & 100.000 \\
\hline
\end{tabular}

Extraction Method: Principal Axis Factoring

\subsection{Multicollinearity}

Table 2 indicated a collinearity test using SmartPLS was done on this study, and it was found that all inner VIF values are less than 5, suggesting no serious collinearity issues between the independent and dependent variables.

Table 2: Collinearity Statistics

\begin{tabular}{llllll}
\hline & C & FRD & ORD & SRD & T \\
\hline C & & & & & \\
FRD & 1.592 & - & - & - & 1.592 \\
ORD & 1.849 & - & - & - & 1.849 \\
SRD & 1.56 & - & - & - & 1.56 \\
T & & & & &
\end{tabular}

Note: $\mathrm{C}=$ Investor Perceived Confidence, FRD = Financial Risk Disclosure, ORD = Operations Risk Disclosure, $\mathrm{SRD}=$ Strategic Risk Disclosure, $\mathrm{T}=$ Investor Perceived Trust

\subsection{Multicollinearity}

\section{Demographic and Socio-Economic Profiles}

As shown in Table 3, there consists of a total of 108 respondents for this study. The collected responses for male and female investors are both $50 \%$. Most respondents who responded are in an age range of less than 25 years old $(46.30 \%)$ while the next largest age group is in an age range of above 55 years old $(28.70 \%)$. In regard to the investor's education level, the majority in this study possess a bachelor's degree (65.74\%). As for investment experience, most have less than one year of experience $(45.37 \%)$ followed by experiences of 2 to 5 years and above 10 years (both $23.15 \%$ ). Lastly, in terms of net monthly income, most respondents have less than RM2,000 (45.37\%) followed by ranges of RM2,000-RM5,000 (21.30\%) and RM5,000RM8,000 (17.59\%).

Table 3. Demographic Profiles of Respondents

\begin{tabular}{lcc}
\hline Demographic Variables & Frequency & Percentage \\
\hline Gender & 54 & \\
Male & 54 & $50.00 \%$ \\
Female & & $50.00 \%$ \\
Age & 50 & $46.30 \%$ \\
Less than 25 years & 17 & $15.74 \%$ \\
25-35 years & & \\
\hline
\end{tabular}




\begin{tabular}{lcr}
\hline 35-45 years & 4 & $3.70 \%$ \\
45-55 years & 6 & $5.56 \%$ \\
More than 55 years & 31 & $28.70 \%$ \\
Education Level & & \\
Secondary School & 2 & $1.85 \%$ \\
Foundation & 0 & $0.00 \%$ \\
Diploma & 15 & $13.89 \%$ \\
Bachelor's Degree & 71 & $65.74 \%$ \\
Master's Degree & 18 & $16.67 \%$ \\
PhD & 2 & $1.85 \%$ \\
Investment Experience & & \\
Less than 1 year & 49 & $45.37 \%$ \\
2-5 years & 25 & $23.15 \%$ \\
5-8 years & 4 & $3.70 \%$ \\
8-10 years & 5 & $4.63 \%$ \\
Above 10 years & 25 & $23.15 \%$ \\
Net Monthly Income & & \\
Less than RM2,000 & 49 & $45.37 \%$ \\
RM2,000-RM5,000 & 23 & $21.30 \%$ \\
RM5,000-RM8,000 & 19 & $17.59 \%$ \\
RM8,000-RM10,000 & 4 & $3.70 \%$ \\
RM 10,000 and above & 13 & $12.04 \%$ \\
\hline Total & 108 & $100 \%$ \\
\hline
\end{tabular}

\section{RESULTS AND DISCUSSION}

SmartPLS was used to test the correlation between the latent variables and the results show that all correlations between financial risk disclosures, operations risk disclosure and strategic risk disclosure significantly correlated with investor perceived confidence and trust (see Table 4).

Table 4. Path Coefficients (N:108)

\begin{tabular}{lllll}
\hline Hypothesis & Relationship & Original Sample & P Values & Results \\
\hline H1 & FRD -> C & 0.406 & 0.000 & Significant \\
& FRD -> T & 0.480 & 0.000 & Significant \\
H2 & ORD -> C & 0.337 & 0.000 & Significant \\
& ORD -> T & 0.214 & 0.001 & Significant \\
H3 & SRD -> C & 0.383 & 0.000 & Significant \\
& SRD -> T & 0.298 & 0.000 & Significant \\
\hline
\end{tabular}

Note: $\mathrm{C}=$ Investor Perceived Confidence, FRD = Financial Risk Disclosure, ORD = Operations Risk Disclosure, $\mathrm{SRD}=$ Strategic Risk Disclosure, $\mathrm{T}=$ Investor Perceived Trust

In multigroup analysis, the interpretation of whether there is a significant difference of the path coefficients for the two groups is the most important [51]. The first step begins by analysing the 2 data groups RI and RS separately prior to determining if there are group specific differences through separate path analysis (see Table 5).

Table 5. Data Groups Formed for COVID-19

\begin{tabular}{|l|l|l|}
\hline Dummy Variable & Items & Records \\
\hline RI & CVD1 (1.0) CVD2 (0.0) & 20 \\
\hline RI & CVD1 (1.0) CVD2 (1.0) & 85 \\
\hline
\end{tabular}




\begin{tabular}{|l|l|l|}
\hline RS & CVD1 (1.0) CVD3 (0.0) & 13 \\
\hline RS & CVD1 (1.0) CVD3 (1.0) & 92 \\
\hline
\end{tabular}

It can be observed in Table 6 that the p values for both groups are closely similar to Table 9 which shows all relationships are significant.

Table 6. Bootstrapping Results for RI and RS

\begin{tabular}{lllll}
\hline & RI & & RS & \\
\hline & $\begin{array}{l}\text { Original } \\
\text { Samples }\end{array}$ & P value & $\begin{array}{l}\text { Original } \\
\text { Samples }\end{array}$ & P value \\
\hline FRD -> C & 0.361 & 0.000 & 0.406 & 0.000 \\
FRD -> T & 0.533 & 0.000 & 0.471 & 0.000 \\
ORD -> C & 0.361 & 0.000 & 0.315 & 0.000 \\
ORD -> T & 0.188 & 0.017 & 0.213 & 0.005 \\
SRD -> C & 0.407 & 0.000 & 0.408 & 0.000 \\
SRD -> T & 0.298 & 0.000 & 0.307 & 0.000 \\
\hline
\end{tabular}

For hypotheses 1, 2 and 3, this study has found a significant positive relationship between financial, operations and strategic risk disclosure to perceived investor confidence and trust. This supports the findings of the studies that have proved overall corporate risk disclosures have provided useful and important information to investors as well as boosting their confidence and trust [9][15][17][18]. In particular, this study provide supports that financial risk disclosures still are useful, valuable and a concern because financial information is still relevant as investors will definitely lean towards clear and concise financial risk disclosures [7][8]. Next, operations risk disclosures are also found to be a concern and factor for investors in their decision making due to its operation loss being a significant impact on a company's value [12][13][14]. Finally, the presences of strategic risk disclosures are also found to be another important factor to investors in their assessment and perception of a company's risk [19][20].

For hypotheses 4, 5 and 6, this study has not found any significant difference on the relationship of COVID-19's impact or improvement towards financial, operations and strategic risk disclosures to perceived investor confidence and trust. In addition, as to whether COVID-19 improves or impacts investor confidence and trust could not also be compared opposing each other due to both groups RI (relationship improved) and RS (relationship significant) do not have too many differences, implying no moderating role. Thus, it can be concluded that both dummy variables RI (relationship improved) and RS (relationship significant) are significantly similar to each other.
Nevertheless, the majority of investors have acknowledged that COVID-19 did have both significant impact and improvement towards their perceived confidence and trust towards financial, operations and strategic risk disclosure

\section{IMPLICATION}

From this study, investor perceptions of confidence and trust in corporate risk disclosures appear relevant and valuable to its users, namely investors. The presence of corporate risk disclosures has confirmed its use again to positively affect investors' perceptions and reduce information asymmetry despite being pressured by risk and uncertainty of COVID-19 [27]. This in turn can possibly increase companies' sustainability and value as investors approve of the disclosures presented have informational relevance [15][41][52]. On the other hand, COVID-19 is thought to cause negative impacts on financial risk attitudes [22][53]. Nevertheless, this study's findings imply that investors accept COVID-19's presence in improving and impacting their confidence and trust in corporate risk disclosures. The presence of corporate risk disclosures had increased investor's trust which lowered the level of uncertainty and perceived risks [3]. Thus, this supports Lopatta et. al. [30] in agreement that investors highly valued companies that include critical global developments, such as COVID-19, in their reporting as a sign of transparency. 


\section{CONCLUSION AND RECOMMENDATION}

Firstly, due to limited resources, accessibility and the ongoing pandemic, the methods of data collection have been limited very much towards online surveys and contacts under a restricted timeline. The collected sample size of 108 is considered the minimum and may be insufficient even though Ramayah et. al. [48] suggested the minimum sample size for PLS-SEM can be 30 to 100 observations. Secondly, the research framework is narrow with it being limited to only 3 types of corporate risk disclosures. This can be expanded further to other types of corporate governance disclosures other than corporate risk disclosures. Thirdly, the study is conducted within Malaysian geographical borders and the results may vary between different countries. Due to the differences in types of stock markets between different countries around the world, the reactions of investors may differ in unstabilised circumstances or crises caused by COVID-19 [1]. Finally, this study was conducted with a relatively minimal sample size of 108 despite having done bootstrapping samples of 500 with the help of an advanced software like SmartPLS. Thus, this sample size may not be sufficient enough to represent the entire population Malaysian individual investors and their perspective on corporate risk disclosures in Malaysia. This limitation is expected to be overcome for further research.

\section{REFERENCES}

[1] Harjoto, MA, Rossi, F, Lee, R, and Sergi, B.S, "How do equity markets react to COVID-19? Evidence from emerging and developed countries", Journal of Economics and Business, vol.115, 2020. DOI: https://doi.org/10.1016/j.jeconbus.2020.105966.

[2] Budiarso, N.S., Hasyim, A. W., Soleman, R., Zam, I. Z, and Pontoh, W, "Investor behavior under the Covid-19 pandemic: The case of Indonesia," Investment Management and Financial Innovations, Vol. 17, No. 3, pp. 308318, 2020.2 DOI: http://dx.doi.org/10.21511/imfi.17(3).2020.23.

[3] Chiah, M. and Zhong, A., "Trading from home: The impact of COVID-19 on trading volume around the world," Finance Research Letters, Vol. 37, $2020 . \quad$ DOI: https://doi.org/10.1016/j.frl.2020.101784.

[4] Barrafrem, K., Västfjäll, D, and Tinghög, G., "Financial well-being, COVID-19, and the financial better-than-average-effect," Journal of Behavioral and Experimental Finance, Vol. 28,
2020.

DOI:

https://doi.org/10.1016/j.jbef.2020.100410.

[5] Ortmann, R, Pelster, M, and Wengerek, ST, "COVID-19 and investor behavior." Finance Research Letters, Vol. 37, 2020. DOI: https://doi.org/10.1016/j.frl.2020.101717.

[6] Zadeh, F.O, and Eskandari, A, "Looking forward to financial risk disclosure practices by Malaysian firms," Australian Journal of Basic and Applied Sciences, Vol. 6, No. 8, 2012. Available: http://www.ajbasweb.com/old/ajbas/2012/Augus t/208-214.pdf.

[7] Hassan, M.S, and Mohd-Saleh, N, "The Malaysian firms listed in the main board of Bursa Malaysia." International Journal of Economics and Management, Vol. 4, No. 2. 2010. DOI: http://www.ijem.upm.edu.my/vol4no2/bab03.pdf

[8] Lawrence, A, "Individual Investors And Financial Disclosure." Journal of Accounting and Economics, Vol. 56, No. 1, 2013. DOI: http://dx.doi.org/10.1016/j.jacceco.2013.05.001.

[9] Miihkinen, A, "The usefulness of firm risk disclosures under different firm riskiness, investor-interest, and market conditions: New evidence from Finland," Advances in Accounting, Vol. 29, No. 2, 2013. DOI: http://dx.doi.org/10.1016/j.adiac.2013.09.006.

[10] Arshad, R, and Ismail, R.F, "Discretionary Risks Disclosure: A Management Perspective." Asian Journal of Accounting and Governance, Vol. 2, No. $1, \quad 2011 . \quad$ DOI: https://doi.org/10.17576/AJAG-2011-2-6543.

[11] Cummins, J.D, Lewis, C.M, and Wei, R, "The market value impact of operational loss events for US banks and insurers," Journal of Banking and Finance, Vol. 30, No. 10, 2006. DOI: https://doi.org/10.1016/j.jbankfin.2005.09.015.

[12] Gillet, R, Hübner, G, and Plunus, S, "Operational risk and reputation in the financial industry," Journal of Banking and Finance, Vol. 34, No. 1, $2010 . \quad$ DOI: http://dx.doi.org/10.1016/j.jbankfin.2009.07.020.

[13] Neifar, S, and Jarboui, A, "Corporate governance and operational risk voluntary disclosure: Evidence from Islamic banks," Research in International Business and Finance, Vol. 46, No. 146, $2018 . \quad$ DOI: https://doi.org/10.1016/j.ribaf.2017.09.006.

[14] Karyani, E, Dewo, S.A, Frensidy, B, and Santoso, W, "Role of risk governance in promoting operational risk disclosure and performance: An Asean-5 banking perspective," International Journal of Business and Society, Vol. 20, No. 3, $2019 . \quad$ Available: http://repository.ibs.ac.id/1574/2/639-role-of- 
risk-governance-in-promoting-operational-riskdisclosure-and-performance-an-asean-5banking-perspective.

[15] Santos, J.G.C.D, and Coelho, A.C, "Valuerelevance of disclosure: Risk factors and risk management in Brazilian firms," Revista Contabilidade e Financas, Vol. 29, No. 78, 2018. DOI: https://doi.org/10.1590/1808$057 \times 201806150$.

[16] Benlemlih, M, Shaukat, A, Qiu, Y, and Trojanowski, G, "Environmental and social disclosures and firm risk." Journal of Business Ethics, Vol. 152, No. 3, 2018. DOI: https://doi.org/10.1007/s10551-016-3285-5.

[17] Lee, J, and Shailer, G, "The effect of boardrelated reforms on investors' Confidence," Australian Accounting Review, Vol. 18, No. 2, 2008. Available: https://doi.org/10.1111/j.18352561.2008.0014.x [Accessed 17 May 2021]

[18] Tong, S.C, "Exploring corporate risk transparency: Corporate risk disclosure and the interplay of corporate reputation, corporate trust and media usage in initial public Offerings," Corporate Reputation Review, Vol. 16, No 2, 2013. DOI: http://dx.doi.org/10.1057/crr.2013.4.

[19] Chauhan, Y, and Kumar, S.B, "Do investors value the nonfinancial disclosure in emerging markets?" Emerging Markets Review, Vol. 37, pp. 32-46, 2018. DOI: https://doi.org/10.1016/j.ememar.2018.05.001.

[20] Kim, H, and Yasuda, Y, "Business Risk disclosure and firm risk: Evidence from Japan." Research in International Business and Finance, Vol. 45, pp. 413-426, 2018. DOI: https://doi.org/10.1016/j.ribaf.2017.07.172.

[21] Cabedo, J. D, and Tirado, J. M, "The disclosure of risk in financial statements," Accounting Forum, Vol. 28, No. 2, pp. 181-200, 2004. DOI: https://doi.org/10.1016/j.accfor.2003.10.002.

[22] Heo, W, Grable, J.E, and Rabbani, A. G, “A test of the association between the initial surge in COVID-19 cases and subsequent changes in financial risk tolerance", Review of Behavioral Finance, Vol. 13, No. 1, pp. 3-19, 2020. DOI: https://doi.org/10.1108/RBF-06-2020-0121.

[23] Yıldırım, M, and Güler, A, "Factor analysis of the COVID-19 perceived risk scale: A preliminary study," Death Studies, pp. 1-8, 2020, DOI: $\quad$ https://doi.org/10.1080/07481187.2020. 1784311 .

[24] Moumen, N, Othman, H. B, and Hussainey, K, "The value relevance of risk disclosure in annual reports: Evidence from MENA emerging markets," Research in International Business and
Finance, Vol. 34, pp. 177-204, 2015. DOI: https://doi.org/10.1016/j.ribaf.2015.02.004

[25] Li, M.C, Lai, C.C, and Xiao, L, "Did COVID-19 increase equity market risk exposure? Evidence from China, The UK, and The US." Applied Economics Letters, Vol. 00, No. 00, pp. 1-5, 2021. Availabe:

https://doi.org/10.1080/13504851.2021.1912696. [Accessed 7 May 2021]

[26] Zimmer, J.C,, Arsal, R.E, Al-Marzouq, M, and Grover, V, "Investigating online information disclosure: Effects of information relevance, trust and risk," Information and Management, Vol. 47, No. 2, pp. 115-123, 2010. DOI: https://doi.org/10.1016/j.im.2009.12.003.

[27] Derouiche, I, Manita, R, and Muessig, A, "Risk disclosure and firm operational efficiency", Annals of Operations Research, Vol. 297, No. 12, pp. 115-145, 2021. DOI: https://doi.org/10.1007/s10479-020-03520-z.

[28] Biell, L, and Muller, A, "Sudden crash or long torture: The timing of market reactions to operational loss events," Journal of Banking and Finance, Vol. 37, No. 7, pp. 2628-2638, 2013. DOI:

http://dx.doi.org/10.1016/j.jbankfin.2013.02.022.

[29] Liu, H, Manzoor, A, Wang, C.Y, Zhan, L, and Manzoor Z, "The COVID-19 outbreak and affected countries stock markets response." International Journal of Environmental Research and Public Health, Vol. 17, No. 8, 2020. [Online]. Available: https://www.mdpi.com/16604601/17/8/2800. [Accessed 2 July 2021]

[30] Lopatta, K, Alexander, E. K, Gastone, L.M, and Tammen, T, "To report or not to report about Coronavirus? The role of periodic reporting in explaining capital market reactions during the global COVID-19 pandemic," SSRN Electronic Journal, 2020.2 DOI: https://dx.doi.org/10.2139/ssrn.3567778.]

[31] Elshandidy, T, and Zeng, C, "The value relevance of risk-related disclosure: Does the tone of disclosure matter?" Borsa Istanbul Review, In Press, 2021. DOI: https://doi.org/10.1016/ j.bir.2021.06.014.

[32] Nagar, V, Schoenfeld, J, and Wellman, L, "The effect of economic policy uncertainty on investor information asymmetry and management disclosures." Journal of Accounting and Economics, Vol. 67, No. 1, pp. 36-57, 2019. DOI: https://doi.org/10.1016/j.jacceco.2018.08.011.

[33] Hair, J.F, Page, M, and Brunsveld, N, Essentials of Business Research Methods 4th ed., Routledge. 2020. 
[34] Sekaran, U, and Bougie, R, Research Methods for Business: A Skill-Building Approach 7th ed., John Wiley \& Sons, Inc, West Sussex. 2016.

[35] Creswell, J.W., Educational Research: Planning, Conducting and Evaluating Quantitative Research and Qualitative Research 4th ed., Pearson Education, Boston. 2012.

[36] Nayak, M.S.D.P, and Narayan, K.A, "Strengths and weakness of online surveys." IOSR Journal of Humanities and Social Science, Vol. 24, No. 5, pp. 31-38, 2019. [Online]. Available: www.iosrjournals.org31\%7CPage. [Accessed 23 June 2021]

[37] Hensen, B, CRS MackworthYoung, Abdelmagid, M, Banda, J, Mavodza, Doyle, AM, Bonell, and Weiss, HA, "Remote Data Collection For Public Health Research In A COVID-19 Era: Ethical Implications, Challenges And Opportunities." Health Policy and Planning, Vol. 36, No. 3. 2021. DOI: https://doi.org/10.1093/heapol/czaa158 [Accessed 5 June 2021]

[38] Prommegger, B, Thatcher, J. B, Wiesche, M, and Krcmar, H, "When your data has COVID-19: How the changing context disrupts data collection and what to do about it,", European Journal of Information Systems, Vol. 30, No 1, pp. 100-118, 2021. DOI: https://doi.org/10.1080/0960085X. 2020.1841573

[39] Linsley, P.M and Shrives, P.J, "Risk reporting: A study of risk disclosures in the annual reports of UK companies," British Accounting Review, Vol. 38, No. 4, pp. 387-404, 2006. DOI: https://doi.org/10.1016/j.bar.2006.05.002.

[40] Amran, A., Manaf Rosli Bin, A, and Che Haat Mohd Hassan, B, "Risk reporting: An exploratory study on risk management disclosure in Malaysian annual reports," Managerial Auditing Journal, Vol. 24, No. 1, pp. 39-57, 2009.DOI: https://doi.org/10.1108/02686900910919893.

[41] Abdullah, M, Shukor, Z.A, Mohamed, Z.M, and Ahmad, A, "Risk management disclosure: A study on the effect of voluntary risk management disclosure toward firm value," Journal of Applied Accounting Research, Vol. 16, No. 3, pp. 400432, 2015. DOI: https://doi.org/10.1108/JAAR10-2014-0106.

[42] Wilson, R, "Limited business knowledge investors perceptions of auditor independence in the provision of assurance on unregulated nonfinancial disclosures,", Journal of Business \& Economics Research (JBER), Vol. 13, No 1, pp. 7-8, 2015.2 DOI: https://doi.org/10.19030/jber.v13i1.9075.
[43] Lucarelli, C, Uberti, P, and Brighetti, G, "Misclassifications in financial risk tolerance," Journal of Risk Research, Vol. 18, No. 4, pp. 467482, $2015 \quad$ DOI: https://doi.org/10.1080/13669877.2014.910678

[44] Kalay, A, "Investor sophistication and disclosure clienteles," Review of Accounting Studies, Vol. 20, No. 2, pp. 976-2011, 2015. DOI: http://dx.doi.org/10.1007/s11142-015-9317-z.

[45] Jamal, A.A.A, Ramlan, W.K, Pazim, K.H, and Budin, D.S.A, "Decision-making style and investment success of retail investors in Malaysia," International Journal of Business and Social Science, Vol. 5, No. 9(1), pp. 311-322, 2014. [Online]. Available: https://www.semanticscholar.org/paper/Decision -Making-Style-and-Investment-Success-of-inJamal-

Ramlan/1ef77fab79f10785ac77b4849f30b7ddb1 7a8fa. [Accessed 22 June 2021]

[46] Khan, M.T.I, Tan, S.H, and Chong, L.L, "Active trading and retail investors in Malaysia," International Journal of Emerging Markets, Vol. 12, No. 4, pp. 708-726, 2017. DOI: https://doi.org/10.1108/IJoEM-03-2016-0063.

[47] Weston, R, and Gore, P.A, "A brief guide to structural equation modelling," The Counseling Psychologist, Vol. 34, No. 5. Pp. 719-751, 2006. Available:

https://journals.sagepub.com/doi/10.1177/00110 00006286345. [Accessed 16 June 2021]

[48] Ramayah, T, Cheah, J, Chuah, F, Ting, H, and Memon, M.A, Partial Least Squares Structural Equation Modeling (PLS-SEM) using SmartPLS 3.0, 2nd edn, Pearson, Kuala Lumpur,2018.

[49?] Hair, J, Hollingsworth, C.L Randolph, A.B and Chong, A.Y.L, "An updated and expanded assessment of PLS-SEM in information systems research," Industrial Management and Data Systems, Vol. 117, No. 3, pp. 442-458, 2017. DOI: https://doi.org/10.1108/IMDS-04-20160130 .

[49?] Hair, J, Hult, G.T, Ringle, C, and Sarstedt, M, A Primer on Partial Least Squares Structural Equation Modeling (PLS-SEM) - Joseph F. Hair, Jr., G. Tomas M. Hult, Christian Ringle, Marko Sarstedt 2nd ed., Sage Publications, Inc. 2017.

[50] Eichhorn, B.R, "Common Method Variance Techniques," Midwest SAS Users Group. 2014. [Online]. Available: https://www.lexjansen.com/ mwsug/2014/AA/MWSUG-2014-AA11.pdf [Accessed 3 June 2021]

[51] Latan, H., Noonan, R. and Matthews, L. Partial least squares path modeling: basic concepts, methodological issues and applications", 2017. 
[Online]. Available: https://doi.org/10.1007/9783-319-64069-3. [Accessed: May 2, 2021].

[52] Hashim, F, and Koon, L.T, "Corporate risk management disclosure and sustainability of public listed companies in Malaysia: The role of diversification," Global Business \& Management Research, Vol. 9, No. 4, pp. 1-16, 2016. [Online]. Available:https://www-proquest-com.tarcez.tarc. edu.my/scholarly-journals/corporate-riskmanagement-disclosure/docview/ 1988803516/ se-2 . accountid=38945. [Accessed 25 May 2021]

[53] Mertens, G, Gerritsen, Duijndam, S, Salemink, E, and Engelhard, I. M, "Fear of the coronavirus (COVID-19): Predictors in an online study conducted in March 2020," Journal of anxiety disorders, Vol. 74, 102258, 2020. DOI: https://doi.org/10.1016/j.janxdis.2020.102258

[54] Babakus, E, and Mangold, WG, “Adapting the servqual scale to a private hospital emergency services: An empirical investigation," Chinese Business Review, Vol. 13, No. 5, pp. 273-289, 2014. DOI: https://doi.org/10.17265/1537$1506 \% 2 \mathrm{~F} 2014.05 .001$.
[55] Bouranta, N, Chitiris, L, and Paravantis, J, "The relationship between internal and external service quality," International Journal of Contemporary Hospitality Management, Vol. 21, No. 3. Pp. 275293, 2009.2 DOI: http://dx.doi.org/10.1108/09596110910948297.

[56] Dawes, J, "Do data characteristics change according to the number of scale points used? an experiment using 5-point, 7-point and 10-point scales," International Journal of Market Research, Vol. 50, No. 1, pp. 61-104, 2008. DOI: https://doi.org/10.1177\%2F14707853080500010 6.

[57] Sachdev, S, and Verma, H, "Relative importance of service quality dimensions: a multisectoral study," Journal of services research, Vol. 4, No. 1, pp. 93-116, 2004. [Online]. Available: https://www-proquestcom.tarcez.tarc.edu.my/scholarlyjournals/relative-importance-service-qualitydimensions/docview/195567847/se2 . accountid=38945. [Accessed 5 September 2021] 